\title{
The Application of Citric Acid in Combination with Some Micronutrients Increases the Growth, Productivity and a Few Chemical Constituents of Maize (Zea Mays) Plants
}

\author{
Mohamed A. Seif El-Yazal \\ Botany Department, Faculty of Agriculture, Fayoum University, Fayoum 63514, Egypt \\ mas04@fayoum.edu.eg
}

Keywords: Citric acid; chemical constituents; growth; micronutrients; Fe, $\mathrm{Mn}$ and $\mathrm{Zn}$ fertilizers; yield.

\begin{abstract}
The objective of this investigation was to study the helpful effects of foliar application with antioxidant citric acid in combos with some micronutrients on growth, yield and a few chemical constituents of maize (Zea mays L.) plants. The plants were grown up in clay soil, and foliar sprayed with eleven treatments $(0,0.05,0.1,0.15,0.2,0.25,0.3,0.35,0.4,0.45$ and $0.5 \%)$ of combined fertilizer (citrine) which contains (15\% citric acid, 2\% Fe, 2\% Mn and 2\% Zn). The obtained results indicated generally that each one studied vegetative growth parameters (i.e. plant height, stem diameter, number of leaves / plant, dry weight of leaves) similarly as grain yield /fed. and some of their components (i.e. ear length, ear diameter, number of rows/ear, number of grains/row, grain weight/ear, weight of 100 grain and ear weight/plant) and some chemical constituents of leaves (chlorophyll a, b, total caroteniods, anthocyanin, total carbohydrates, total and reducing sugars, total free amino acids, total indoles, nitrogen, phosphorous and potassium) and grain protein $\%$, were accrued with application of the various treatments. The maximum values were obtained from the treatment of $0.3 \%$. On the contrary citrine treatments minimized reducing sugars and free phenol in leaves as compared to the control. The simplest results were obtained by the application of citrine treatment at $0.3 \%$. Hence, it can recommend using citrine fertilizers as foliar application at the speed of $0.3 \%$ for improving growth, yield and chemical constituents of maize plants.
\end{abstract}

\section{Introduction}

Maize (Zea mays L.) is associate degree annual plant. It's cultivated globally being one amongst the foremost necessary cereal crops worldwide. It's a flexxible crop grown over a variety of agro climatical zones. It's known as "Queen of Cereals" due to its high productive potential compared to the other cereal crop. It's a C4 plant; it is capable to utilize solar radiation a lot of expeditiously even at higher radiation intensity [1]. In Egypt, nice attention has been paid to extend its total production. Therefore, efforts are being targeted on increasing the productivity of maize crop by growing high yielding varieties and/or raising the agronomical follow like fertilization.

Citric acid improves the antioxidant content of foods since it stimulates a larger synthesis of nutraceutical compounds that function as antioxidants, among that are the phenolic compounds and flavonoids among them [2]. They have a synergistic impact on growth, yield and a few chemical constituents of the many crops yet as dominant the incidence of most fungi on many crops [3]. Several investigations show a rise within the content of compounds with bioactive properties in maize by the applying of compounds that perform as elicitors since they promote the synthesis of compounds derived from phenylpropanoids and activate signal cascades that increase antioxidant activity [4]. Some of the mentioned works have studied the applying of compounds like citric acid $[5,4,3]$, salicylic acid [6-9], ascorbic acid [10, 11], benzoic acid [12]. Micronutrients have a useful impact of on growth, yield and a few chemical constituents of maize plants as reported by many workers [13, 14, 1, 15]. However, in Egypt, soils plagued by some deficiencies of micronutrients particularly Fe, $\mathrm{Zn}$ and $\mathrm{Mn}$ [16]. Consequently, the aim of this work was to check the result of exogenous application of citrine (citric acid, Fe, $\mathrm{Zn}$ and $\mathrm{Mn}$ ) at different rates on growth, yield, as 
well as some chemical constituents of maize plants during 2015 and 2016 seasons by the aim of increasing maize productivity.

\section{Materials and Methods}

This investigation was applied throughout the two sequential seasons of 2015 and 2016 at the Experimental space in clay soil at the college of Agriculture, Fayoum, University, Egypt. Before planting the foremost vital physical and chemical characters of the chosen soil was determined according to [17] as shown in Table 1.

Table 1. The physical and chemical analysis of the used soil before planting in both seasons

\begin{tabular}{|c|c|c|c|}
\hline \multicolumn{2}{|c|}{ Properties } & 2015 & 2016 \\
\hline \multicolumn{4}{|c|}{ Physical } \\
\hline \multicolumn{2}{|c|}{ Sand \% } & 26.78 & 27.05 \\
\hline \multicolumn{2}{|c|}{ Silt \% } & 26.70 & 26.10 \\
\hline \multicolumn{2}{|c|}{ Clay \% } & 46.52 & 46.85 \\
\hline \multicolumn{2}{|c|}{ Texture grade } & Clay & Clay \\
\hline \multicolumn{4}{|c|}{ Chemical } \\
\hline \multicolumn{2}{|c|}{ Organic matter $\%$} & 1.78 & 1.76 \\
\hline \multicolumn{2}{|c|}{$\mathrm{pH}(1: 2.5)$} & 7.35 & 7.27 \\
\hline \multicolumn{2}{|c|}{$\mathrm{Ec}\left(\mathrm{ds} \mathrm{m}^{-1}\right)$} & 0.63 & 0.67 \\
\hline \multicolumn{2}{|c|}{$\mathrm{CaCO}_{3} \%$} & 5.62 & 5.47 \\
\hline \multirow{7}{*}{ 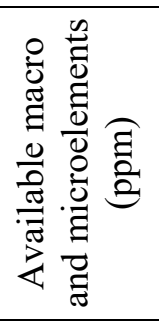 } & $\mathrm{N}$ & 475.00 & 482.00 \\
\hline & $\mathrm{P}$ & 419.00 & 426.00 \\
\hline & $\mathrm{K}$ & 21.20 & 24.10 \\
\hline & $\mathrm{Fe}$ & 85.20 & 83.50 \\
\hline & $\mathrm{Zn}$ & 27.99 & 27.09 \\
\hline & $\mathrm{Mn}$ & 3.40 & 3.25 \\
\hline & $\mathrm{Cu}$ & 0.78 & 0.74 \\
\hline
\end{tabular}

In all experiments, the different treatments were arranged in randomized complete design with three replications. The experimental plot was $4 \times 3.5 \mathrm{~m}\left(14 \mathrm{~m}^{2}\right)$ contained 5 rows each of $4 \mathrm{~m}$ long and $70 \mathrm{~cm}$ width, each plot contains 66 plants. Maize triple hybrid 310 was hand sown at the rate of $15 \mathrm{~kg}$ seeds/fed. in hills $30 \mathrm{~cm}$ apart in June $26^{\text {th }}$ in the two seasons. After 21 days from sowing, plants were thinned to a single plant per hill on one side of the ridge. Phosphorous as calcium super phosphate $\left(15.5 \% \mathrm{P}_{2} \mathrm{O}_{5}\right)$ at the rate of $200 \mathrm{~kg} / \mathrm{fed}$., was added to the field before sowing. Nitrogen at the rate of $150 \mathrm{~kg} \mathrm{~N} / \mathrm{fed}$. as urea $(46 \% \mathrm{~N})$ and potassium sulphate $\left(48 \% \mathrm{~K}_{2} \mathrm{O}\right)$ at the rate of $100 \mathrm{~kg} / \mathrm{fed}$., were given in two equal doses. The first dose was added after thinning (21 days from sown), the second dose given after 30 days from the first one. The other cultural practices of growing maize at Fayoum Governorate were followed as normal. The plants were sprayed with tap water (as a control) or citrine (containing 15\% citric acid, $2 \% \mathrm{Fe}, 2 \% \mathrm{Zn}, 2 \% \mathrm{Mn}, 3 \%$ adhesive sugar substances and $76 \%$ water) at two times; the first was sprayed after thinning with a volume $150 \mathrm{~L} /$ fed. and the second was applied three wakes later with a volume $150 \mathrm{~L} /$ fed. Triton B as a wetting agent at $0.1 \%$ was added to the antioxidant solutions. Spraying was carried out till runoff.

The experiment involved the following treatments

1- Control (spraying with tap water)

3- Spraying with citrine at rate $0.1 \%$

5- Spraying with citrine at rate $0.2 \%$

7- Spraying with citrine at rate $0.3 \%$

9- Spraying with citrine at rate $0.4 \%$

11 - Spraying with citrine at rate $0.5 \%$
2- Spraying with citrine at rate $0.05 \%$

4- Spraying with citrine at rate $0.15 \%$

6- Spraying with citrine at rate $0.25 \%$

8 - Spraying with citrine at rate $0.35 \%$

10 - Spraying with citrine at rate $0.45 \%$ 


\section{Data recorded}

\section{1- Growth characters}

Two plant samples were taken from each experimental plot. The first (ten plants from each treatment in the three replications) was taken 75 days after planting to study the following traits (i.e. plant height $(\mathrm{m})$, stem diameter $(\mathrm{cm})$, number of leaves / plant and dry weight of leaves per plant $(\mathrm{g})$. The second sample was taken at harvesting time four months from planting (ten plants were chosen randomly from each plot) to estimate ear length $(\mathrm{cm})$, ear diameter $(\mathrm{cm})$, number of rows/ear, number of grains/ row, grain weight/ear $(\mathrm{g})$, weight of 100 grain $(\mathrm{g})$, ear weight/plnt $(\mathrm{g})$ and grain yield/ fed (ton).

\section{Chemical analysis}

Fresh and dried leaves and seeds (75 days of old plants for leaves and at harvest, after 120 days from planting for seeds) were used for determination of the following constituents: Photosynthetic pigments: chlorophyll $\mathrm{a}, \mathrm{b}$ and total caroteniods were extracted from fresh leaves by acetone $(80 \%)$ then, their concentrations were determined as $\mathrm{mg} / 100 \mathrm{~g}$ fresh weight according to [18]. Total carbohydrates $\mathrm{mg} / \mathrm{g}$ dry weight were determined colorimetrically by using phenolsulphuric acid reagent according to the method described by [19]. Total and reducing sugars were determined using phosphomolybdic acid reagent as described by [20] and recorded as $\mathrm{mg} / \mathrm{g}$ dry weight. Anthocyanin concentration ( $\mathrm{mg} / 100 \mathrm{~g}$ dry weight) was determined according to the method described by [21]. Total free amino acids in fresh leaves were determined colorimetrically using ninhydrin reagent according to the method described by [22] and recorded as $\mathrm{mg} / \mathrm{g}$ dry weight. Total indoles $\mathrm{mg} / \mathrm{g}$ fresh weight were determined by using 4-dimethylaminobenzaldehyde reagent as described by [23]. Free phenols in fresh leaves were determined using Folin-Denis reagent as described by [20] and recorded as $\mathrm{mg} / \mathrm{g}$ dry weight. Nitrogen $\%$, in leaves and crude protein percentage in seeds, was determined according to [20], phosphorus \% was determined according to [20], potassium was determined by Flame Photometer, Parkin-Elmer model 52 according to the method described by [24].

\section{Statistical analysis}

The experiment was in a complete randomized block design with 11 treatment and 3 replicates for each treatment. Results were statistically analyzed using the L.S.D. at probability level of 5\% for comparisons according to [25].

\section{Results}

\section{Growth characters}

Data presented in Table 2 clearly indicate that sparing maize plants with the antioxidant and micronutrients namely citrine at the rates from 0.05 up to $0.5 \%$ improved the studied growth parameters of maize plant, i.e. plant height, stem diameter, number of leaves/plant and dry weight of leaves /plant as compared to the control plants. Such trend was true during the two studied seasons. The highest increase was recorded with citrine foliar spray at the rate $0.3 \%$ which surpassed the control by 22.39 and $22.66 \%$ for plant height, 32.06 and $32.38 \%$ for stem diameter, 5.63 and $7.09 \%$ for number of leaves/plant and 8.20 and $8.31 \%$ for dry weight of leaves/ plant respectively in both seasons over the control plants. 
Table 2. Effect of citrine (citric acid in combination with some micronutrients) on plant height, stem diameter, number of leaves /plant and dry weight of leaves maize (Zea mays L.) plants on 2015 and 2016 seasons

\begin{tabular}{|c|c|c|c|c|c|c|c|c|c|}
\hline \multirow{2}{*}{\multicolumn{2}{|c|}{ Treatments }} & \multicolumn{2}{|c|}{$\begin{array}{c}\text { Plant height } \\
\text { (m) }\end{array}$} & \multicolumn{2}{|c|}{$\begin{array}{c}\text { Stem } \\
\text { diameter }(\mathbf{c m})\end{array}$} & \multicolumn{2}{|c|}{$\begin{array}{l}\text { Number of } \\
\text { leaves/plant }\end{array}$} & \multicolumn{2}{|c|}{$\begin{array}{l}\text { Dry weight of } \\
\text { leaves/plant (g) }\end{array}$} \\
\hline & & 2015 & 2016 & 2015 & 2016 & 2015 & 2016 & 2015 & 2016 \\
\hline \multirow{11}{*}{ 泀 } & 0.00 & 2.01 & 2.03 & 2.09 & 2.10 & 14.10 & 14.20 & 70.15 & 70.18 \\
\hline & 0.05 & 2.10 & 2.16 & 2.13 & 2.15 & 14.40 & 14.30 & 73.20 & 73.33 \\
\hline & 0.10 & 2.23 & 2.24 & 2.27 & 2.29 & 14.52 & 14.59 & 73.80 & 73.95 \\
\hline & 0.15 & 2.30 & 2.34 & 2.50 & 2.51 & 14.70 & 14.80 & 74.86 & 74.91 \\
\hline & 0.20 & 2.35 & 2.38 & 2.60 & 2.62 & 14.80 & 14.90 & 75.60 & 75.53 \\
\hline & 0.25 & 2.40 & 2.44 & 2.65 & 2.68 & 14.80 & 14.90 & 75.66 & 75.70 \\
\hline & 0.30 & 2.46 & 2.49 & 2.76 & 2.78 & 15.10 & 15.00 & 75.90 & 76.01 \\
\hline & 0.35 & 2.44 & 2.47 & 2.73 & 2.75 & 14.90 & 14.90 & 75.80 & 75.87 \\
\hline & 0.40 & 2.42 & 2.44 & 2.70 & 2.72 & 14.90 & 14.90 & 75.39 & 75.34 \\
\hline & 0.45 & 2.40 & 2.43 & 2.69 & 2.72 & 14.90 & 14.90 & 75.20 & 75.23 \\
\hline & 0.50 & 2.40 & 2.42 & 2.69 & 2.71 & 14.80 & 14.80 & 75.19 & 75.12 \\
\hline \multicolumn{2}{|c|}{ L.S.D at $0.5 \%$} & 0.21 & 0.26 & 0.18 & 0.22 & 0.42 & 0.39 & 2.60 & 2.69 \\
\hline
\end{tabular}

\section{Grain yields and their components}

Data in Tables 3 and 4 indicate that foliar application of citrine at the concentrations from 0.05 up to $0.5 \%$ increased grain yields and its components (ear length, ear diameter, number of rows/ear, number of grains/row, grain weight/ear, weight of 100 grain, ear weight/plant and grain yield/ fed.) as compared to the control plants. Such trend was true during the two studied seasons. The data also show that the promotion occurred in such yield and its components under this study were associated with the increase in citrine levels from 0.05 to $0.3 \%$ and thereafter, a slight decreased were generally occurred by using concentration more than $0.3 \%$, but the values were still over the control one treatment. The maximum increase was recorded with citrine foliar application at the rate $0.3 \%$ which recorded 14.04 and $15.64 \%$ for ear length, 12.94 and $13.35 \%$ for ear diameter, 6.92 and $6.11 \%$ for number of rows/ear, 4.55 and $4.81 \%$ for number of grains/row, 26.91 and $27.26 \%$ for grain weight/ear, 14.44 and $13.53 \%$ for weight of 100 grain, 44.32 and $43.38 \%$ for ear weight/plant and 26.89 and $27.26 \%$ for grain yield/ fed in the first and second seasons respectively over the control plants.

Table 3. Effect of citrine (citric acid in combination with some micronutrients) on ear length, ear diameter, number of rows/ear and number of grains/ row of maize (Zea mays L.) plants on 2015 and 2016 seasons

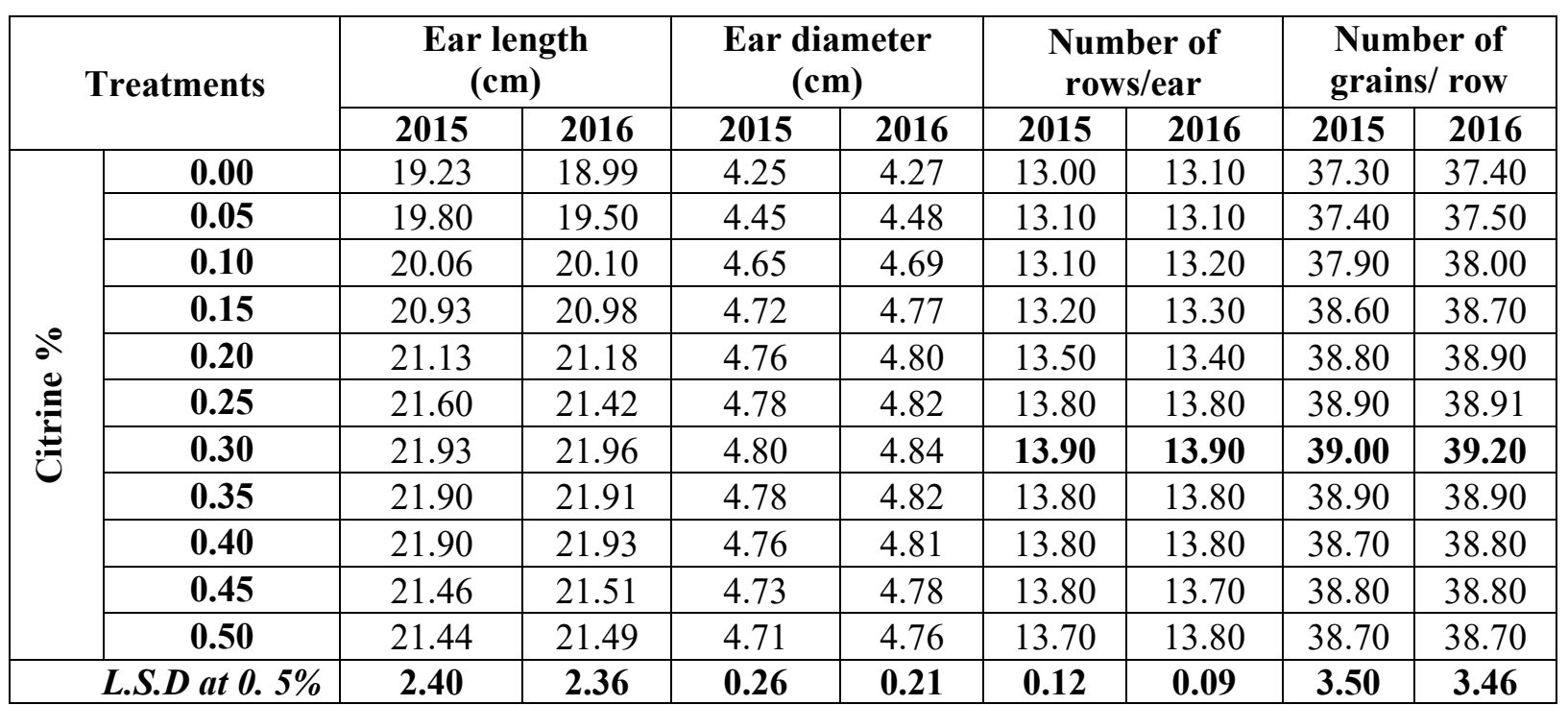


Table 4. Effect of citrine (citric acid in combination with some micronutrients) on grains weight/ear, weight of 100 grain, ear weight/plant and grains yield/ fed. of maize (Zea mays L.) plants on 2015 and 2016 seasons

\begin{tabular}{|c|c|c|c|c|c|c|c|c|c|}
\hline \multicolumn{2}{|c|}{ Treatments } & \multicolumn{2}{|c|}{ Grain weight/ear (g) } & \multicolumn{2}{|c|}{$\begin{array}{l}\text { Weight of } \\
100 \text { grain (g) }\end{array}$} & \multicolumn{2}{|c|}{$\begin{array}{l}\text { Ear weight } \\
\text { /plant (g) }\end{array}$} & \multicolumn{2}{|c|}{$\begin{array}{l}\text { Grain yield/ } \\
\text { fed.(ton) }\end{array}$} \\
\hline & & 2015 & 2016 & 2015 & 2016 & 2015 & 2016 & 2015 & 2016 \\
\hline \multirow{11}{*}{ نَّ } & $\mathbf{0 . 0 0}$ & 174.18 & 178.44 & 35.92 & 36.42 & 190.71 & 193.74 & 3.484 & 3.569 \\
\hline & 0.05 & 176.72 & 179.65 & 36.07 & 36.57 & 200.82 & 203.34 & 3.534 & 3.593 \\
\hline & 0.10 & 180.02 & 184.38 & 36.26 & 36.76 & 230.60 & 233.17 & 3.600 & 3.687 \\
\hline & 0.15 & 186.28 & 190.75 & 36.56 & 37.06 & 236.13 & 238.67 & 3.725 & 3.815 \\
\hline & 0.20 & 211.09 & 212.67 & 40.30 & 40.80 & 257.15 & 259.68 & 4.221 & 4.253 \\
\hline & 0.25 & 218.75 & 221.49 & 40.75 & 41.25 & 269.16 & 271.68 & 4.375 & 4.429 \\
\hline & 0.30 & 221.06 & 227.10 & 40.78 & 41.68 & 275.23 & 277.79 & 4.421 & 4.542 \\
\hline & 0.35 & 214.24 & 216.92 & 39.91 & 40.41 & 270.33 & 272.86 & 4.284 & 4.338 \\
\hline & 0.40 & 211.75 & 214.97 & 39.65 & 40.15 & 265.42 & 267.98 & 4.235 & 4.299 \\
\hline & 0.45 & 208.23 & 209.38 & 38.89 & 39.39 & 261.51 & 264.05 & 4.164 & 4.187 \\
\hline & 0.50 & 205.28 & 209.45 & 38.72 & 39.22 & 255.61 & 258.12 & 4.105 & 4.189 \\
\hline \multicolumn{2}{|c|}{ L.S.D at $0.5 \%$} & 15.67 & 15.75 & 1.61 & 1.68 & 14.23 & 14.08 & 0.612 & 0.622 \\
\hline
\end{tabular}

\section{Chemical constituents of plants}

\section{Leaf pigments concentration}

Data presented in Table 5 clearly show in two successive seasons that, the concentration of leaf pigments (chlorophyll a, b, total caroteniods and anthocyanin) were significantly increased when maize plants were sprayed with citrine (citric acid, Zn, Fe and Mn) at the rates from 0.05 up to $0.5 \%$ as compared to the control. The best results were observed when maize plants were sprayed with citrine at the rate of $0.3 \%$ which recorded 23.72 and $23.55 \%$ for chlorophyll a, 17.35 and $17.17 \%$ for chlorophyll b, 28.83 and $25.75 \%$ for total caroteniods and 14.60 and $15.06 \%$ for anthocyanin in the first and second seasons respectively over the control plants.

\section{Total soluble carbohydrates, total and reducing sugars and total free amino acids concentration}

Data recorded in Table 6 clearly revealed in the two successive seasons that, all used concentration of citrine increased total soluble carbohydrates, total sugars and total free amino acids as compared to the control plants. The highest increase was recorded with citrine foliar application at the rate of $0.3 \%$ which recorded 45.37 and $46.78 \%$ for total carbohydrates and 14.60 and $14.60 \%$ for total sugars and 89.53 and $88.75 \%$ for total free amino acids in the first and second seasons respectively over the control plants.

On the contrary, reducing sugars content were decreased by using the same concentrations used in the study as compared to the control plants. 
Table 5. Effect of citrine (citric acid in combination with some micronutrients) on chlorophyll a, b, total caroteniods and anthocyanin concentration of maize (Zea mays L.) plants on 2015 and 2016 seasons

\begin{tabular}{|c|c|c|c|c|c|c|c|c|c|}
\hline \multicolumn{2}{|c|}{ Treatments } & \multicolumn{2}{|c|}{$\begin{array}{l}\text { Chlorophyll a } \\
\text { mg/100g F.W }\end{array}$} & \multicolumn{2}{|c|}{$\begin{array}{l}\text { Chlorophyll b } \\
\text { mg/100g F.W }\end{array}$} & \multicolumn{2}{|c|}{$\begin{array}{c}\text { Total } \\
\text { caroteniods } \\
\text { mg/100g F.W }\end{array}$} & \multicolumn{2}{|c|}{$\begin{array}{l}\text { Anthocyanin } \\
\text { mg/100g D.W }\end{array}$} \\
\hline & & 2015 & 2016 & 2015 & 2016 & 2015 & 2016 & 2015 & 2016 \\
\hline \multirow{11}{*}{ 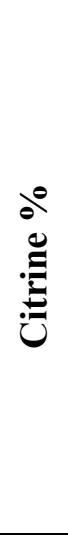 } & 0.00 & 138.32 & 139.91 & 80.62 & 81.46 & 15.21 & 15.26 & 59.06 & 59.25 \\
\hline & 0.05 & 140.13 & 141.92 & 83.01 & 83.85 & 15.74 & 16.79 & 61.09 & 61.20 \\
\hline & 0.10 & 151.15 & 152.72 & 88.52 & 89.36 & 16.92 & 17.07 & 62.11 & 62.33 \\
\hline & 0.15 & 155.08 & 156.63 & 93.01 & 93.85 & 17.85 & 18.00 & 63.13 & 63.60 \\
\hline & 0.20 & 162.18 & 163.84 & 93.01 & 93.85 & 18.03 & 18.68 & 65.17 & 65.42 \\
\hline & 0.25 & 166.35 & 167.95 & 93.31 & 94.15 & 19.03 & 19.08 & 67.20 & 67.61 \\
\hline & 0.30 & 171.14 & 172.86 & 94.61 & 95.45 & 19.14 & 19.19 & 79.24 & 79.29 \\
\hline & 0.35 & 169.01 & 170.94 & 92.01 & 92.85 & 17.85 & 17.09 & 78.12 & 78.17 \\
\hline & 0.40 & 166.11 & 167.61 & 90.01 & 90.85 & 17.51 & 17.06 & 76.37 & 76.42 \\
\hline & 0.45 & 165.94 & 167.44 & 89.00 & 89.84 & 16.91 & 16.96 & 74.25 & 74.30 \\
\hline & 0.50 & 165.31 & 166.80 & 88.81 & 89.65 & 16.81 & 16.76 & 73.15 & 73.20 \\
\hline & L.S.D at $0.5 \%$ & 10.64 & 10.89 & 7.23 & 7.05 & 1.43 & 1.37 & 2.41 & 2.28 \\
\hline
\end{tabular}

Table 6. Effect of citrine (citric acid in combination with some micronutrients) on total carbohydrates, total sugars, reducing sugars and total free amino acids concentration of maize (Zea mays L.) plants on 2015 and 2016 seasons

\begin{tabular}{|c|c|c|c|c|c|c|c|c|c|}
\hline & \multirow[t]{2}{*}{ Treatments } & \multicolumn{2}{|c|}{$\begin{array}{c}\text { Total } \\
\text { carbohydrates mg/g } \\
\text { D.W }\end{array}$} & \multicolumn{2}{|c|}{$\begin{array}{l}\text { Total sugars } \\
\text { mg/g D.W }\end{array}$} & \multicolumn{2}{|c|}{$\begin{array}{l}\text { Reducing sugars } \\
\text { mg/g D.W }\end{array}$} & \multicolumn{2}{|c|}{$\begin{array}{l}\text { Total free } \\
\text { amino acid } \\
\mathrm{mg} / \mathrm{g} \text { D.W }\end{array}$} \\
\hline & & 2015 & 2016 & 2015 & 2016 & 2015 & 2016 & 2015 & 2016 \\
\hline \multirow{11}{*}{ 泀 } & 0.00 & 97.91 & 98.01 & 48.97 & 49.12 & 16.69 & 16.80 & 6.97 & 7.02 \\
\hline & 0.05 & 120.84 & 122.52 & 50.10 & 50.75 & 15.27 & 15.60 & 8.23 & 8.27 \\
\hline & 0.10 & 133.55 & 135.62 & 52.60 & 52.75 & 13.69 & 13.85 & 8.46 & 8.51 \\
\hline & 0.15 & 136.76 & 138.83 & 52.97 & 53.12 & 13.37 & 13.41 & 13.05 & 13.08 \\
\hline & 0.20 & 139.93 & 140.53 & 53.30 & 54.45 & 13.10 & 13.21 & 13.09 & 13.12 \\
\hline & 0.25 & 140.12 & 141.93 & 55.00 & 55.75 & 12.63 & 12.71 & 13.15 & 13.18 \\
\hline & 0.30 & 142.33 & 143.86 & 56.12 & 56.52 & 11.05 & 11.11 & 13.21 & 13.25 \\
\hline & 0.35 & 140.16 & 141.89 & 55.10 & 55.25 & 11.59 & 12.05 & 9.32 & 9.46 \\
\hline & 0.40 & 138.58 & 139.66 & 53.18 & 53.33 & 13.59 & 13.09 & 8.56 & 8.58 \\
\hline & 0.45 & 136.64 & 137.79 & 52.12 & 52.27 & 16.32 & 15.30 & 8.51 & 8.56 \\
\hline & 0.50 & 134.51 & 135.71 & 51.23 & 51.38 & 16.60 & 16.71 & 8.35 & 8.41 \\
\hline \multicolumn{2}{|c|}{ L.S.D at $0.5 \%$} & 9.94 & 10.45 & 3.28 & 3.60 & 3.66 & 3.20 & 1.24 & 1.29 \\
\hline
\end{tabular}

\section{Total indoles and free phenols}

Data recorded in Table 7 clearly indicate in the two successive seasons that, total indoles and free phenols were affected by the application of citrine at all used rates compared with the control plants. The best result was obtained when maize plants were sprayed with citrine at the rate of $0.3 \%$ which recorded 10.44 and $10.53 \%$ for total indoles in the first and second seasons respectively over the control plants. On the contrary a marked decrease in free phenols concentration in leaves was recorded by the application of citrine at all used rates comparing with the control plants.

\section{Nitrogen, phosphorus and potassium concentrations}

Data in both seasons of the study are presented in Tables 7 and 8 revealed that leaves of maize plants contained a high concentration of nitrogen, phosphorus and potassium under foliar spray with citrine comparing to control plants. The maximum increase was obtained when citrine was an 
application at the rate of $0.3 \%$ which recorded 21.45 and $21.49 \%$ for nitrogen, 6.53 and $6.58 \%$ for phosphorous and 19.92 and $20.08 \%$ for potassium in both seasons respectively as compared to the control plants.

\section{Grains crude protein\%}

Data presented in Table 8 clearly show that spraying maize plants with the citrine (antioxidant) at the rates from 0.05 up to $0.5 \%$ significantly improved grain crude protein content as compared to the control plants. Such trend was true during the two studied seasons. The highest increase was recorded when citrine was sprayed at the rate of $0.3 \%$ which surpassed the control by 24.51 and $24.75 \%$ in the first and second seasons respectively, as compared to the control plants.

Table 7. Effect of citrine (citric acid in combination with some micronutrients) on total indoles, total phenols and nitrogen concentration of maize (Zea mays L.) plants on 2015 and 2016 seasons

\begin{tabular}{|c|c|c|c|c|c|c|c|}
\hline \multicolumn{2}{|c|}{ Treatments } & \multicolumn{2}{c|}{$\begin{array}{c}\text { Total indoles mg/g } \\
\text { D.W }\end{array}$} & \multicolumn{2}{c|}{$\begin{array}{c}\text { Free phenols } \\
\text { mg/g D.W }\end{array}$} & \multicolumn{2}{c|}{ Nitrogen \% } \\
\cline { 3 - 8 } \multicolumn{2}{|c|}{} & $\mathbf{2 0 1 5}$ & $\mathbf{2 0 1 6}$ & $\mathbf{2 0 1 5}$ & $\mathbf{2 0 1 6}$ & $\mathbf{2 0 1 5}$ & $\mathbf{2 0 1 6}$ \\
\hline \multirow{4}{*}{} & $\mathbf{0 . 0 0}$ & 2.47 & 2.49 & 5.72 & 5.70 & 3.01 & 3.03 \\
\cline { 2 - 8 } & $\mathbf{0 . 0 5}$ & 2.51 & 2.53 & 4.04 & 4.01 & 3.32 & 3.36 \\
\cline { 2 - 8 } & $\mathbf{0 . 1 0}$ & 2.56 & 2.59 & 3.70 & 3.63 & 3.47 & 3.48 \\
\cline { 2 - 8 } & $\mathbf{0 . 1 5}$ & 2.61 & 2.63 & 3.36 & 3.26 & 3.49 & 3.51 \\
\cline { 2 - 8 } & $\mathbf{0 . 2 0}$ & 2.65 & 2.68 & 3.35 & 3.18 & 3.53 & 3.56 \\
\cline { 2 - 8 } & $\mathbf{0 . 2 5}$ & 2.70 & 2.72 & 3.02 & 3.00 & 3.59 & 3.61 \\
\cline { 2 - 8 } & $\mathbf{0 . 3 0}$ & $\mathbf{2 . 7 3}$ & $\mathbf{2 . 7 5}$ & $\mathbf{2 . 6 9}$ & $\mathbf{2 . 5 8}$ & $\mathbf{3 . 6 6}$ & $\mathbf{3 . 6 8}$ \\
\cline { 2 - 8 } & $\mathbf{0 . 3 5}$ & 2.71 & 2.72 & 3.36 & 3.16 & 3.56 & 3.61 \\
\cline { 2 - 8 } & $\mathbf{0 . 4 0}$ & 2.68 & 2.69 & 3.89 & 3.95 & 3.55 & 3.57 \\
\cline { 2 - 8 } & $\mathbf{0 . 4 5}$ & 2.62 & 2.63 & 3.99 & 3.99 & 3.54 & 3.55 \\
\cline { 2 - 8 } & $\mathbf{0 . 5 0}$ & 2.61 & 2.62 & 4.04 & 3.99 & 3.52 & 3.53 \\
\hline \multirow{3}{*}{ L.S.D. at 0. 5\% } & $\mathbf{0 . 0 4}$ & $\mathbf{0 . 0 8}$ & $\mathbf{1 . 0 2}$ & $\mathbf{1 . 0 7}$ & \multirow{2}{*}{$\mathbf{0 . 3 1}$} & $\mathbf{0 . 3 4}$ \\
\hline
\end{tabular}

Table 8. Effect of citrine (citric acid in combination with some micronutrients) on the leaf (phosphorous and potassium \%) and grain protein\%, of maize (Zea mays L.) plants on 2015 and 2016 seasons

\begin{tabular}{|c|c|c|c|c|c|c|c|}
\hline \multirow{2}{*}{\multicolumn{2}{|c|}{ Treatments }} & \multicolumn{2}{|c|}{ Phosphorous\% } & \multicolumn{2}{|c|}{ Potassium \% } & \multicolumn{2}{|c|}{ Grain protein \% } \\
\hline & & 2015 & 2016 & 2015 & 2016 & 2015 & 2016 \\
\hline \multirow{11}{*}{ 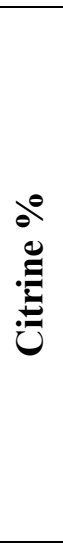 } & 0.00 & 0.304 & 0.306 & 2.59 & 2.61 & 9.09 & 9.18 \\
\hline & 0.05 & 0.315 & 0.317 & 2.74 & 2.73 & 9.95 & 9.98 \\
\hline & 0.10 & 0.316 & 0.317 & 2.78 & 2.80 & 9.96 & 10.05 \\
\hline & 0.15 & 0.317 & 0.318 & 2.83 & 2.85 & 10.09 & 10.18 \\
\hline & 0.20 & 0.318 & 0.319 & 2.91 & 2.93 & 10.28 & 10.37 \\
\hline & 0.25 & 0.319 & 0.320 & 2.97 & 2.99 & 10.78 & 10.37 \\
\hline & 0.30 & 0.324 & 0.326 & 3.11 & 3.13 & 11.34 & 11.43 \\
\hline & 0.35 & 0.320 & 0.322 & 3.05 & 3.07 & 11.02 & 11.11 \\
\hline & 0.40 & 0.315 & 0.317 & 2.94 & 2.96 & 10.86 & 10.95 \\
\hline & 0.45 & 0.315 & 0.317 & 2.91 & 2.94 & 10.85 & 10.94 \\
\hline & 0.50 & 0.314 & 0.317 & 2.90 & 2.92 & 10.83 & 10.92 \\
\hline \multicolumn{2}{|c|}{ L.S.D at $0.5 \%$} & 0.03 & 0.01 & 0.15 & 0.12 & 0.85 & $\mathbf{0 . 8 0}$ \\
\hline
\end{tabular}




\section{Discussion}

Spraying maize plants with citric acid combined with some micronutrients (Fe, $\mathrm{Mn}$ and $\mathrm{Zn}$ ) namely citrine resulted in vigorous growth also as extremely productivity of seeds with sensible quality. An increasing the measured growth characters (plant height etc.) was thanks to that these fertilizers leading to a lot of accessibility micronutrients ( $\mathrm{Fe}, \mathrm{Mn}$ and $\mathrm{Zn}$ ) and antioxidant like citric acid to be absorbed by the recorded plants. The positive result of the antioxidants included citric acid on growth could be attributed to their positive action on enhancing cell divisions and protective plant cells from free radicals that's accountable for plant senescence, , additionally to be attributed to their result on counteracting drought, salinity and diseases stresses as well as they have an auxinic action, consequently enhancing plant growth characters and stimulates a greater synthesis of nutraceutical compounds that function as antioxidants, among which are the phenolic compounds and flavonoids among them [2, 26, 27]. Citric acid can degrade conjugated phenols such as tannins to other simpler phenolic compounds by hydrolyzing and promotes the synthesis of compounds derived from phenylpropanoids and activates signaling cascade that increase antioxidant activity [3, 28]. These compounds can accumulate in cellular vacuoles [29]. Moreover, micronutrients utilized in this study ( $\mathrm{Zn}, \mathrm{Fe}$ and $\mathrm{Mn}$ ) even have an up impact on vegetative growth parameters. This might be attributed to the essential role of $\mathrm{Zn}$ in synthesis of tryptophan amino acid and consequently formation of growth regulator, i.e. IAA that act as plant hormone particularly in prolonging height of plants [30]. In this concern, [31-33] reported that zinc rapidly increases the photosynthetic activity and translocation of photosynthates to growing onion bulbs. Moreover, [34] reported that, the increase in growth characters might be due to the critical role of iron nutrient in crop growth, involving in photosynthesis processes, respiration and other biochemical and physiological activates. The stimulating result of the used micronutrients on plant growth could also be thanks to their role in transmission of the lepton from water to pigment and manufacturing gas within the chemical process, additionally to their role within the element metabolism through activated group enzyme protein [35]. Also, the favorable result of the used nutrients on stem diameter could also be thanks to their stimulation effect on cellular division and expansion. Moreover, the rise in dry weight of leaves/plant may be attributed to its stimulating result on vegetative growth and physiological processes, i.e. increasing number of cells through cellular division and meristematic activity of tissues. Increasing number of leaves/plant (Table 2) by micronutrients application could be also attributed to the increment in cellular division and cell elongation. The stimulating result of the used micronutrients on plant growth could be thanks to their role in transmission of the lepton from water to pigment and manufacturing gas within the photosynthesis, additionally to their role within the nitrogen metabolism through activated nitrite reductase enzyme [35]. The improving effect of citric acid and micronutrients on yield and its components was mainly attributed to its positive action on enhancing growth parameters (Table 2) and photosynthetic pigments of plants leaves (Table 4). In this respect, [36] stated that antioxidant especially ascorbic acid has an auxinic action and conjointly synergistic result on the biosyntheses of sugars and dominant the incidence of most fungi on plants makes them in vigorous states that consequently is mirrored on seed yield. Moreover, the rise in yield and its parts could also be attributed to the metabolic role of $\mathrm{Zn}, \mathrm{Fe}$ and $\mathrm{Mn}$ in the plant. In this respect, [37] suggested that grain yield might generally be restricted by chemical change (source) and grain (sink) at the same time and it's attainable to extend grain yield by keeping safe the balance between them. The favorable impact of $\mathrm{Zn}, \mathrm{Fe}$ and $\mathrm{Mn}$ on grain yield and its components may well be attributed to the rise in photosynthetic pigments concentration [38] additionally as enzyme activity, that consequently enhancing plant metabolism [39]. Also, zinc has essential role in super molecule metabolism, macromolecule synthesis, essential amino acid and IAA synthesis, since it activates range of enzymes for chemical action [40, 41]. The encouraging impact of citrine on leaf pigments concentration could be attributed to the enhancing effect of antioxidants and micronutrients on the nutritionary standing of maize plants. In this respect, [27, 42] stated that the majority antioxidants were chargeable for fast the biogenesis of varied pigments resulting in the rise in biosynthesis of sugars. Moreover, [43] show that anthocyanins could play a crucial role within the prevention of lipid peroxidation of cell membranes elicited by active oxygen 
radicals. Moreover, the stimulating result of micronutrients on chlorophyll formation, total carbohydrates and total sugars concentration were according by [44] who expressed that this increase could also be because of the enhancing result of $\mathrm{Fe}, \mathrm{Mn}$ and $\mathrm{Zn}$ on chlorophyll formation and consequently photosynthesis. In addition, the decrease in reducing sugars by citrine (citric acid, $\mathrm{Zn}, \mathrm{Fe}$ and $\mathrm{Mn}$ ) application may be attributed to the high capacity of the plant sprayed with this substance in building up non reducing sugars (sucrose) from the simple sugars, which decreased. In this respect, [38] reportable that the essential perform of metal in plant was associated with its role in carbohydrates metabolism. The increase in total indoles and total free amino acids may be attributed to the role of $\mathrm{Zn}$ in synthesis of tryptophan (amino acid) and consequently the formation of natural auxin in plants, i.e. indole 3 -acetic acid (IAA). In addition, the reduction in free phenols contrasted with the increase in total indoles, i.e. endogenous promoters increased and consequently endogenous inhibitors decreased in the leaves leading to an increase in plant growth parameters such as plant height and leaves number/plant as shown in Table 2. In this respect, [45] showed that the result of phenoplast compounds on plant growth was contributed to either the antagonism with IAA activity. The rise in macronutrients ( $\mathrm{N}, \mathrm{P}$, and $\mathrm{K}$ ) were supported by the results of [46] United Nations agency rumored that the result of antioxidants on manufacturing healthy plants ends up in enhancing the plants to possess a good ability for uptake mineral elements. Moreover, [47] reported that, the rise in leaves $\mathrm{N}, \mathrm{P}$ and $\mathrm{K}$ could also be because of the result of $\mathrm{Zn}$ on synthesis of plant hormones (IAA) that promote rooting process and root distribution and consequently the amounts of mineral elements absorbed by roots and translocated into the various parts of the plant. Also, [48, 49] recorded that the utilization of micronutrients as foliar fertilizers semiconductor diode to a rise in root growth and thereby higher uptake of macro and micronutrients. The rise in protein content of grain could also be attributed to the increment in total nitrogen percent of leaves and grains. During this respect, $\mathrm{Zn}$ has a vital role in protein syntheses [40, 41, 49, 50].

\section{Conclusions}

Finally, from the current results, it may well be over that the appliance of citrine (citric acid, $\mathrm{Fe}, \mathrm{Zn}$, and $\mathrm{Mn}$ ) greatly accumulated growth and grain yield also as improved grain quality and its chemical constituents. These parts participate within the totally different metabolic processes that accumulated syntheses of pigment, carbohydrates, total free amino acids, IAA and absorption of essential nutrients, so the used micronutrients with antioxidants may well be increase maize productivity with prime quality seeds.

\section{Conflict of Interest}

The authors declare that there is no conflict of interest.

\section{References}

[1] C.L. Borase et al., Response of Kharif maize (Zea mays L.) to micronutrients, Journal of Pharmacognosy and Phytochemistry. 7(3) (2018) 482-484.

[2] S. Pérez-Balibrea, D.A. Moreno, C. García-Viguera, Influence of light on health-promoting phytochemicals of broccoli sprouts, J. Sci. Food Agric. 88 (2008) 904-910.

[3] L. Salas-Pérez et al., The application of citric acid increases the quality and antioxidant capacity of lentil sprouts, Revista Mexicana de Ciencias Agrícolas special. 20(1) (2018) 4301-4309.

[4] M. Świeca, B. Baraniak, Nutritional and antioxidant potential of lentil sprouts affected by elicitation with temperature stress, J. Agric. Food Chem. 62 (2014) 3306-3313.

[5] J.A. Ulloa et al., Effect of soaking conditions with citric acid, ascorbic acid and potassium sorbate on the physicochemical and microbiological quality of minimally processed jackfruit, CyTA. J. Food. 8 (2010) 193-199. 
[6] E. Yildirim, A. Dursum, Effect of foliar salicylic acid applications on plant growth and yield of tomato under greenhouse conditions, Acta Hortic. 807 (2009) 395-400.

[7] S.A. Larqué et al., Efecto del ácido salicílico en el crecimiento de plántulas de tomate (Lycopersicum esculentum Mill), Rev. Chapingo Ser. Hortic. 16 (2010) 183-187.

[8] A.A. Amin et al., Physiological effects of salicylic acid and thiourea on growth and productivity of maize plants in sandy soil, Commun. Soil Sci. Plant Anal. 44 (2016) 1141-1155.

[9] D. D. A. Vázquez et al., Efecto del ácido salicílico en la producción y calidad nutracéutica de frutos de tomate, Rev. Mex. Cienc. Agríc. 17 (2016) 3405-3414.

[10] A. R. y Torres, A. F. M. Calvo, Enfermedad hipertensiva del embarazo y el calico, Rev. Cubana de Obstetricia y Ginecología. 37 (2011) 551-561.

[11] S.H. Gad El-Hak, A.M. Ahmed, Y.M.M. Moustafa, Effect of foliar application with two antioxidants and humic acid on growth, yield and yield components of peas (Pisum sativum L.), Journal of Horticultural Science \& Ornamental Plants. 4 (3) (2012) 318-328.

[12] Sh. A. Anjum et al., Exogenous benzoic acid (BZA) treatment can induce drought tolerance in soybean plants by improving gas-exchange and chlorophyll contents, Aust. J. Crop Sci. 7 (2013) 555-560.

[13] M.A. Siddika et al., Effect of different micronutrients on growth and yield of rice, International Journal of Plant \& Soil Science. 12(6) (2016) 1-8.

[14] M.T. Rahman et al., Effects of micronutrient on growth and micronutrient content of hybrid maize (Zea mays L.), Bangladesh Journal of Botany. 46(1) (2017) 527-532.

[15] N. Abd EL-Kader, Effect of nitrogen applications, micronutrients and cyanobacteria on wheat yield and the availability of some nutrients, Egypt. J. Soil. Sci. 58 (1) (2018) 105-111.

[16] A.F.A. Fawzi, Micronutrients effect on field crops in Egypt, Proc. $4^{\text {th }}$ Micronutrients Work Shop, Amman, Jordan, 1991, pp. 3-30.

[17] S.A. Wilde et al., Soil and Plant Analysis For Tree Culture $3^{\text {rd }}$ Ed. Oxford IBLT Publishing Co., New Delhi, (1985), pp. 9-100.

[18] A.R. Welburn, H. Lichtenthaler, Formula and program to determine total caroteniods and chlorophyll $\mathrm{a}$ and $\mathrm{b}$ of leaf extracts different solvents, In Advances in photosynthesis Research (Sybesma C.Ed.) Vol., II, 1984, pp. 9-12, Mortinus Njihoff Dr. W. Junk publishers, the Hague.

[19] D. Herbert, P. J. Phipps, R. F. Strange, Determination of total carbohydrates, Methods in Microbian. 5 (B) (1971) 209-244.

[20] A.O.A.C., Official Methods of Analysis of the Association of Official Agricultural Chemists, $16^{\text {th }}$ ed., (1995) Washington D.C., USA.

[21] R.E. Hoagland, Effect of glycophosphate on metabolism of phenolic compounds, VI. Effect of glyphosime and glyphosate metabolites on phenylalanine ammonia lyase activity, growth, protein and chlorophyll and anthocyanin levels in soybean seedlings, Weed Sci. 28 (1980) 393 -409.

[22] J. Jayarman, Laboratory Manual in Biochemistry, Wiley Eastern Limited New York, 1981, pp. $61-73$.

[23] P. Larson et al., On the biogenesis of some indole compounds in Acetobacter xylimum, Physiol. Plant. (15) (1962) 552-565.

[24] A. I. Page, R. H. Miller, D. R. Keeny, "Methods of Soil Analysis", Part II. Chemical and Microbiological Methods. $2^{\text {nd }}$ Ed. Amer. Soc. Agron., Madison, Wisconsin, USA (1982).

[25] K.A.Gomez, A.A. Gomez, Statistical Analysis Procedure of Agricultural Research. John Wiley and Sons, New York, 1983, pp. 25-30. 
[26] I. Raskin, Salicylate, a new plant hormone, Plant Physiol. 99 (1992) 799- 803.

[27] Y. Elade, The use of antioxidants to control gray mould (Botrytis cineria) and white mould (Sclerotinia sclerotiorum) in various crops, Plant Pathol. 141 (1992) 417-426.

[28] S. A. Larqué et al., Efecto del ácido salicílico en el crecimiento de plántulas de tomate (Lycopersicum esculentum Mill). Rev. Chapingo Ser. Hortic. 16 (2010) 183-187.

[29] R. F. Tester, J. Karkalas, X. Qi, Starch-composition, fine structure and architecture, J. Cereal Sci. 39 (2004) 151-165.

[30] T. Devendra, C.L. Najda, D. Tak, Effect of growth regulators on growth and flower yield of tuberouse (Polianthes tuberosa L.) cv. Single, Scientific Hort. 6 (1999) 147-150.

[31] D. Manna, T.K. Maity, Growth, yield and bulb quality of onion (Allium cepa L.) in response to foliar application of boron and zinc. Journal of Plant Nutrition. 39 (3) (2016) 438-441.

[32] D. Manna, T.K. Maity, A. Ghosal, Influence of foliar application of boron and zinc on growth, yield and bulb quality ofonion (Allium cepaL.). Journal of Crop and Weed.10 (1) (2014) 53-55.

[33] V. Aske et al., Effect of Micronutrients on Yield, Quality and Storability of Onion cv. Bhima Super. Trends in Biosciences.10 (6) (2017) 1354-1358.

[34] M.S. Zeidan, M.F. Mohamed, H.A. Hamouda, Effect of foliar fertilization of Fe, Mn and Zn on wheat yield and quality in low sandy soils fertility, World J. Agric. Sci. 6 (2010) 696-699.

[35] M.S. Baza, Effect of some macro and micro elements on growth and yields of maize. M.Sc. Thesis, Fac. Agric. Moshtohr, Zagazig Univ., Egypt, 1984.

[36] A.I. Al-Qubaie, Response of Ficus nitida L. seedlings to the application of some antioxidants under soil salinity conditions, Minia J. Agric. Res. Develop. 22 (3) (2002) 235-254.

[37] J.H. Wilson, J.C. Allison, Production and distribution of dry matter in maize following changes in plant population after flowering. Ann. Appl. Biol. 90 (1978) 121-127.

[38] C.A. Price, H.E. Clark, E.A. Funkhouser, Function of micronutrients in plants, Soil Sci., Society of America. (1972) 231.

[39] N.K. Boardman, Trace-elements in photosynthesis. In trace elements in Soil- Plant Animal System. Edited by Nicholas: 1975, pp. 199-212. Academic Press. Inc., New York, San Francisco and London.

[40] F. P. Gardner, R.B. Prearce, R.L. Mitcheell, Physiology of crop plants, The Iowa State Univ. Press. Ames Iowa, U.S.A. (1985).

[41] H. Marschner, Mineral Nutrition of Higher Plants, Academic Press Inc. (London) LTD, 1986, pp. 279-287.

[42] K. M. Farag, Use of urea, phenylalanine, thiamine or their combinations to accelerate anthocyanins development and their effect on the storage life of Flame seedless grapes, First Egyptian Hungarian Hort. Conf., Kafr El-Sheikh, Egypt. (1996) 15-17 Sept.

[43] T. Tsuda et al., Antioxioxidative activity of the anthocyanin pigments cyaniding 3-O-B-Dglucoside and cyaniding, J. Agric. Food Chem. 42 (1994) 2407-2410.

[44] H. Mohr, P.Schopfer, Plant Physiology, Translated by Gudrum and Lawlor, D.W. SpringVerlag, Berlin Heidelberg New York (1995).

[45] F.Sagi, A.S. Garay, The dependence of auction oxidase activity on the photoperiodically conditioned phenol content of the leaves and their age in Lupinus albus, Hort. Abst. 31 (1961) 3688.

[46] F.F. Ahmed, H.M. Abd El-Hameed, Influence of some antioxidants on growth, vine nutritional status, yield and quality of berries in banaty grapevines, Assiut J. Agric. Sci. 35(4) (2004) 131-140. 
[47] R.M. Devlin, F. H. Withman, Plant Physiology.4 $4^{\text {th }}$ Ed. CBS Publishers and Distriibution, 485, Jain Bhawan, Bhola Nath Nagar, Shahdara. Delhi-110 032 (India), 1985, 443.

[48]M.M. El-Fouly, A.F.A. Fawzi, Higher and better yield with less environmental pollution in Egypt through balanced fertilizer use. Fertilize Research. 43 (1996) 1-4.

[49] H. Maralian, Effect of foliar application of $\mathrm{Zn}$ and $\mathrm{Fe}$ on wheat yield and quality, Afr. J. Biotechnol. 8 (2009) 6795-6798.

[50] H. Narimani et al., Study on the effects of foliar spray of micronutrient on yield and yield components of durum wheat, Arch. Applied Sci. Res. 2 (2010) 168-176. 